\title{
Investigasi Pengaruh Luasnya Pengungkapan Sukarela atas Keberadaan Komite Pengawas Manajemen Pada Perusahaan Manufaktur Di Indonesia
}

\author{
Dinalestari Purbawati ${ }^{1, *}$ dan Agung Budiatmo ${ }^{2}$ \\ ${ }^{1,2}$ Departemen Administrasi Bisnis, Fakultas Ilmu Sosial dan Ilmu Politik, Universitas Diponegoro \\ Email: dinapyu@gmail.com
}

\begin{abstract}
This study investigated the impact the existence from the oversight committee on the extent from voluntary disclosure of manufacturing company in Indonesia. The oversight committee consist of risk management committee and nomination and remuneration committe. The existence from the oversight committee of manufacturing companies who have never been broad mandatory will have an influence on the differences in the voluntary disclosure between the company which one with a company that other. Data was collected used a documentation technique from the annual reports manufacturing companies listed on the Indonesian Stock Exchange period 2015 until 2017. Sampling method used purposive sampling. The number of samples were 81 companies each year. Multiple linear regression analysis is tools used in this model. The final results showed that in parsial the existence from the risk management committee (RMC) had a positive significant effect of the extent from voluntary disclosure. In simultan test showed that oversight committee had a positive significant effect on the extent of voluntary disclosure. Suggestions for further research is to be able to add the use of data collection method as questionnaires and interviews in knowing more information about the existence of an oversight committee.
\end{abstract}

\begin{abstract}
Abstraksi: Penelitian ini memiliki tujuan uji pengaruh keberadaan komite pengawas manajemen, yang terdiri atas komite nominasi dan remunerasi (KNR) serta komite pengawas risiko terhadap luas pengungkapan sukarela pada perusahaan manufaktur yang terdaftar di Bursa efek Indonesia. Keberadaan komite pengawas manajemen yang belum termandatkan pada perusahaan manufaktur akan berpotensi mempengaruhi tingkat luasan dari pengungkapan informasi secara sukarela di laporan tahunan antar perusahaan. Teknik dokumentasi adalah teknik pengumpulan data pada penelitian ini, yaitu melalui pengumpulan data dari Annual Report perusahaan manufaktur yang terdaftar di BEI periode 2015, 2016, dan 2017. Pengambilan sampel dilakukan dengan metode purposive sampling. Jumlah sampel penelitian adalah 81 perusahaan per tahunnya. Pada model pengujian menggunakan alat analisis regresi linier berganda. Berdasarkan hasil penelitian ditemukan bahwa secara parsial variabel keberadaan komite pengawas risiko berpengaruh signifikan terhadap luas pengungkapan informasi secara sukarela, secara parsial keberadaan KNR tidak signifikan berpengaruh terhadap luas pengungkapan sukarela. Hasil temuan selanjutnya, diperoleh bahwa secara simultan keberadaan komite manajemen pengawas berpengaruh signifikan terhadap luas pengungkapan sukarela. Saran untuk penelitian selanjutnya adalah dapat menambahkan penggunaan metode pengumpulan data seperti kuesioner maupun wawancara untuk lebih mengetahui informasi secara lengkap mengenai keberadaan komite pengawas manajemen.
\end{abstract}

Keywords:Oversight committee; Risk management; Voluntary disclosure; Corporate governance

\section{Pendahuluan}

Pada saat ini terdapat fenomena bahwa sebagian besar perusahaan di Indonesia membutuhkan peningkatan efektivitas serta kompetensi didalam pencapaian tujuan perusahaan. Efektifitas suatu tata kelola di perusahaan diharapkan dapat membantu dalam penciptaan nilai perusahaan yang berkelanjutan melalui skema pertumbuhan jangka panjang yang sehat. Salah satu bentuk pengimplementasian tata kelola perusahaan yang efektif yaitu melalui komite bentukan Dewan Komisaris. Komite-komite tersebut dapat berupa komite operasi maupun komite pengawas manajemen. Keberadaan komitekomite tersebut memiliki peranan penting dalam manajemen perusahaan. Keduanya merupakan mekanisme efektif agar perusahaan fokus terhadap fungsi pengawasan risiko, manajemen risiko, dan pengendalian internal yang tepat (Subramaniam, et al., 2009).

Di Indonesia, keberadaan komite pengawas manajemen menunjukkan perkembangan. Pemerintah mewajibkan industri finansial untuk membentuk komite pengawas manajemen. Namun demikian, 
pembentukan komite pengawas manajemen di sektor industri non-finansial masih belum diwajibkan. Efektifitas sistem manajemen akan dapat mendukung perusahaan didalam pencapaian tujuan usahanya, berefek pula terhadap peningkatan pelaporan keuangan serta memberi efek positif terhadap reputasi mereka. Pengungkapan informasi yang dilakukan perusahaan, khususnya pengungkapan sukarela adalah cara peningkatan kualitas pelaporan informasi keuangan serta reputasi perusahaan. Maka semakin luas melakukan pengungkapan sukarela, perusahaan akan semakin dinilai lebih.

Kualitas pengungkapan informasi secara sukarela yang terkandung di laporan tahunan, saat ini menjadi inti dari permasalahan keuangan modern. Perusahaan dihadapkan pada krisis kepercayaan yang serius dan perusahaan tersebut tidak dapat berpikir mengenai efisiensi komunikasi keuangan. Dengan demikian, transparansi dan keterbukaan yang lebih berkualitas akan membuat stakeholder perusahaan mempunyai informasi yang lebih lengkap. Hal ini akan menyebabkan alokasi modal yang lebih baik pula di pasar saham (Matoussidan Raida, 2006). Francis, et.al (2005) menemukan pengungkapan secara sukarela yang dilakukan oleh perusahaan akan dapat meningkatkan nilai mereka, karena dengan pengungkapan perusahaan akan terlihat peduli serta lebih jujur terhadap dunia sekitar mereka. Mereka juga menyimpulkan bahwa pengungkapan secara sukarela yang berbentuk pengaturan informasi yang diungkapkan, akan menyebabkan turunnya biaya modal, peningkatan kredibilitas karena dapat mengurangi asimetri atau ketidakseimbangan informasi yang dimiliki oleh agen maupun prinsipal. Menurut Karolyi (1998) diketahui bahwa di Amerika Serikat perusahaan asing mengurangi risiko serta biaya modal secara keseluruhan. Bothwell (2004) berkesimpulan bahwa pengungkapan dapat meningkatkan transparansi, menghindari konflik dan regulasi di masa depan.

Pelaporan keuangan selain berfokus pada akun serta pada informasi kuantitatif dan numerik, tetapi juga berfokus pada informasi kualitatif disertai dengan komentar-komentar dan informasi keuangan tambahan. Ini terjadi karena laporan keuangan tidak cukup untuk memberikan gambaran yang komprehensif bagi kinerja riil perusahaan. Untuk melengkapi "potret" akuntansi perusahaan, maka dihubungkan dengan voluntary disclosure. Pengungkapan informasi secara sukarela didefinisikan sebagai suatu pengumuman fakultatif yang bukan merupakan bagian dari informasi yang bersifat publik. Pengungkapan informasi sukarela juga dapat mengurangi asimetri informasi, sehingga berdampak kepercayaan investor kepada manajemen perusahaan (Kangarlouei, et.al, 2013). Pengungkapan secara sukarela dipengaruhi oleh beberapa karakteristik tertentu perusahaan, salah satunya adalah faktor keberadaan komite pengawas risiko, yaitu KNR serta komite pengawas risiko. Keberadaan komite tersebut berpotensi mempengaruhi perbedaan luasnya pengungkapan informasi secara sukarela di laporan tahunan antar perusahaan.

Salah satu fungsi komite pengawas manajemen adalah mempersiapkan pengungkapan. Dengan adanya komite pengawas manajemen diharapkan pengungkapan yang dilakukan oleh perusahaan akan lebih berkualitas sehingga akan menyebabkan luas pengungkapan sukarelanya akan lebih luas pula. Keberadaan komite pengawas manajemen yang efektif akan membantu perusahaan dalam usaha pencapaian tujuan, peningkatan kualitas pelaporan informasi keuangan serta nilai perusahaan. Salah satu aspek dalam peningkatan kualitas suatu pelaporan informasi keuangan serta menjaga reputasi yaitu melakukan suatu pengungkapan, khususnya pengungkapan secara sukarela. Semakin luas pengungkapan informasi secara sukarela oleh perusahaan, maka perusahaan dinilai lebih transparan dan baik oleh para stakeholder.

Keberadaan komite pengawas manajemen pada perusahaan manufaktur yang belum bersifat mandatory akan berpengaruh pada luas pengungkapan sukarela dalam laporan tahunan antar perusahaan yang satu dengan yang lain. Karena terdapat perbedaan luas pengungkapan inilah, sehingga fenomena ini menarik untuk diteliti.

Penelitian ini akan menguji pengaruh antara keberadaan KNR serta komite pengawas risiko terhadap luas pengungkapan sukarela di 
perusahaan manufaktur yang terdaftar di Bursa Efek Indonesia.

\section{Kajian Teori}

\section{Teori Agensi}

Teori keagenan menurut Jensen et.al. (1976), disimpulkan investor berperan sebagai prinsipal serta manajemen berperan sebagai agen. Dalam teori agensi berpotensi munculnya konflik kepentingan antara prinsipal terhadap agen karena termotivasi oleh kepentingan masing-masing. Untuk mengatur tindakan para agen yang tidak sejalan dengan kepentingan prinsipal, maka prinsipal mempunyai dua cara yaitu, melakukan pengawasan terhadap perilaku agen dengan mengadopsi fungsi auditing serta mekanisme corporate governance lain dan menyediakan insentif yang menarik bagi para agen maupun mengadakan struktur reward yang dapat membujuk para agen agar bertindak sesuai dengan kepentingan prinsipal (Jensen et.al 1976). Konflik kepentingan muncul karena terdapat potensi bahwa agen melakukan moral hazard, dimana situasi ini akan memicu munculnya biaya agensi (Nugroho, 2008).

Teori agensi sering kali digunakan sebagai landasan pada tema penelitian terdahulu mengenai tata kelola perusahaan, terutama terkait keberadaan suatu komite. Relevansi teori ini yaitu pada kepentingan aspek pengawasan untuk terciptanya tata kelola perusahaan yang baik.

Berdasarkan sudut pandang teori agensi, ada dua metode pengawasan terhadap manajemen, yang pertama pengawasan eksternal, yang kedua pengawasan internal. Mekanisme pengawasan internal terdiri dari dewan komisaris serta komite pengawas manajemen (Ruigrok, et.al, 2006) sedangkan pada metode pengawasan eksternal yaitu auditor eksternal (Chen, et.al., 2009).

Keterkaitan teori agensi terhadap keberadaan komite adalah dari aspek pengawasan. Komite bentukan dewan komisaris merupakan kepanjangan tangan dari dewan komisaris sebagai prinsipal untuk melakukan pengawasan atas manajemen selaku agen. Dewan komisaris berharap dengan adanya pengawasan oleh komite bentukannya, manajemen (agen) dapat berperilaku atau bertindak sesuai dengan yang diharapkan oleh dewan komisaris selaku prinsipal.

\section{Teori Legitimasi}

Pada teori legitimasi disimpulkan organisasi secara berkesinambungan akan mencari jalan agar operasional perusahaan sesuai norma serta batas yang berlaku di masyarakat (Deegan, 2004). Perusahaan secara sukarela akan melaporkan aktifitasnya apabila terdapat anggapan bahwa ini adalah harapan masyarakat. Guthrie et.al (1989) menyatakan perusahaan secara berkesinambungan harus menunjukkan telah dapat beroperasi yang selaras terhadap nilai sosial. Hal ini ditunjukkan dengan pengungkapan informasi melalui laporan perusahaan, khususnya pada pengungkapan informasi secara sukarela. Pada pengungkapan sukarela yang luas, informasi perusahaan akan disajikan lebih lengkap untuk para pengguna laporan informasi perusahaan. Hal itu merupakan salah satu strategi perusahaan untuk memperoleh suatu pengakuan dari masyarakat bahwasanya perusahaan telah berjalan sesuai harapan dari masyarakat serta lingkungan sosial.

Kerangka teori yang dibangun untuk penelitian ini ditunjukkan pada Gambar 1.

\section{Hipotesis}

H1: Keberadaan KNR di perusahaan manufaktur berpengaruh terhadap luas pengungkapan sukarela.

$\mathrm{H} 2$ : Keberadaan komite pengawas risiko di perusahaan manufaktur berpengaruh terhadap luas pengungkapan sukarela. 


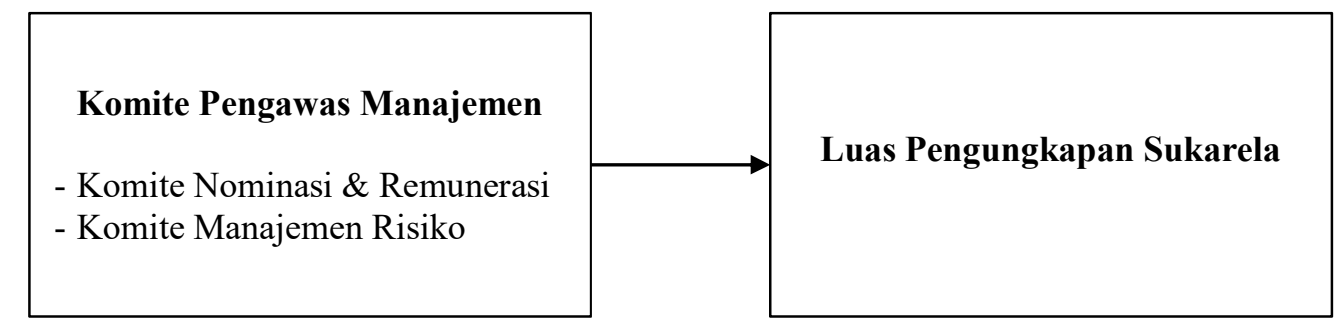

Gambar 1. Kerangka Pemikiran Teoritis

H3: Keberadaan KNR serta komite pengawas risiko di perusahaan manufaktur berpengaruh terhadap luas pengungkapan sukarela.

\section{Definisi Operasional}

\section{Keberadaan KNR}

KNR adalah komite yang berperan membantu para Dewan Komisaris (Dekom) didalam penetapan kualifikasi penentuan calon Dekom serta Direksi maupun sistem remunerasinya, selanjutnya membantu para Dewan Komisaris didalam menyiapkan calon Dekom serta Direksi dan memberikan usulan besaran remunerasi. KNR dapat diukur menggunakan dummy, perusahaan yang mengungkapkan keberadaan komite pengawas risiko pada laporan tahunannya akan diberikan kode satu (1), sedangkan pada sebaliknya diberikan kode nol (0) (Subramaniam, et.al, 2009).

\section{Keberadaan RMC}

Komite pengawas risiko adalah komite bentukan Dewan Komisaris didalam usaha mendukung pelaksanaan tanggung jawab serta tugas Dewan Komisaris terkait pengawasan maupun penerapan manajemen risiko di dalam perusahaan. Komite pengawas risiko dapat diukur menggunakan dummy, perusahaan yang mengungkapkan keberadaan komite pengawas risiko pada laporan tahunannya akan diberikan kode satu (1), sedangkan sebaliknya diberikan kode nol (0).

Luas Pengungkapan Sukarela/Voluntary Disclosure (DSCORE)
Pengungkapan didefinisikan sebagai ketersediaan sejumlah informasi yang dibutuhkan didalam pasar modal efisien untuk pengoperasian optimal (Hendrickson dan Breda, 1992). Pengungkapan sukarela (voluntary disclosure) dapat diukur dengan menggunakan indeks pengungkapan sukarela (voluntary disclosure) yang berjumlah 49 item. Berikut adalah secara garis besar checklist per kelompok butir pengungkapan sukarela:

\section{Tabel 1.Checklist Kelompok Butir Pengungkapan Sukarela}

\begin{tabular}{lc}
\hline Indikator & $\begin{array}{c}\text { Jumlah } \\
\text { Bobot }\end{array}$ \\
\hline Informasi umum pada perusahaan & 7 \\
\hline Informasi tentang Dewan & 7 \\
Komisaris serta Direksi & 5 \\
\hline Evaluasi operasi masa depan & 5 \\
\hline Penelitian serta pengembangan & 10 \\
\hline Informasi tentang karyawan & 6 \\
\hline Pelaporan tanggung jawab social & 3 \\
\hline Peningkatan pada produk serta jasa & 6 \\
\hline Informasi tentang penerapan CG & 49 \\
\hline Jumlah bobot &
\end{tabular}

Daftar indikator yang telah dikembangkan selanjutnya digunakan untuk mengetahui tingkat luasan pengungkapan informasi secara sukarela pada laporan tahunan (annual report) perusahaan.

Berikut adalah perumusan indeks penilaian pengungkapan sukarela: (1) Penentuan bobot pengungkapan informasi bersifat dikotomi; yaitu sebuah item mendapatkan bobot 1 apabila dilakukan pengungkapan, dan 0 apabila tidak diungkapkan. Akan tetapi, apabila terdapat jenis pengungkapan informasi untuk perusahaan tertentu, bobot pengungkapan 
Tabel 2. Koefisien Determinasi

\begin{tabular}{lccc}
\hline Model & R & R Square & Adjusted R Square \\
\hline 1 & $0.670^{\mathrm{a}}$ & 0.449 & 0.444 \\
\hline tidak dikurangi karena tidak melakukan \\
pengungkapan; (2) Pengungkapan informasi \\
yang tidak diberikan bobot, oleh karenanya \\
item pengungkapan diperlakukan secara \\
sama,
\end{tabular}

Dengan demikian, semakin banyak item informasi yang diungkapkan secara sukarela pada daftar yang ditampilkan pada laporan tahunan, semakin besar pula indeks penilaian atas luasnya suatu pengungkapan informasi secara sukarela di perusahaan, begitu pula sebaliknya.

\section{Metode}

Kategori penelitian adalah eksplanatori (explanatory research), selanjutnya dimensi waktu penelitian melibatkan satu waktu tertentu dengan banyak sampel (cross sectional). Populasi di dalam penelitian ini adalah perusahaan yang terdaftar di Bursa Efek Indonesia periode 2015 - 2017. Teknik pengumpulan data di dalam penelitian ini adalah teknik dokumentasi, yaitu mengumpulkan data-data dari Annual Report perusahaan. Sampel penelitian diambil melalui metode purposive sampling. Obyek penelitian yaitu perusahaan yang memiliki beberapa kualifikasi tertentu. Kriteria tersebut adalah perusahaan sektor manufaktur yang terdaftar berturut-turut pada BEI periode 2015 - 2017. Perusahaan di BEI yang termasuk di dalam sektor manufaktur berjumlah 163 perusahaan, dari jumlah tersebut yang dijadikan sampel penelitian sejumlah 81 perusahaan per tahunnya. Alat analisis di dalam penelitian ini yaitu Regresi Linier Berganda.

Sampel didalam penelitian ini dibagi menjadi empat kelompok, yang pertama perusahaan yang memberikan pengungkapan keberadaan KNR, serta perusahaan yang tidak memberikan pengungkapan keberadaan KNR; perusahaan yang memberikan pengungkapan keberadaan komite pengawas risiko, perusahaan yang tidak memberikan pengungkapan keberadaan komite pengawas risiko. Berdasar total sampel berjumlah 243 perusahaan, 145 perusahaan atau 59,7\% memberikan pengungkapan keberadaan KNR, serta 146 perusahaan atau $60,1 \%$ memberikan pengungkapan keberadaan komite pengawas risiko. Sebanyak 44 perusahaan memberikan pengungkapan keberadaan KNR pada tahun 2015, sebanyak 49 perusahaan pada tahun 2016, dan 52 perusahaan pada tahun 2017. Selanjutnya, sebanyak 43 perusahaan memberikan pengungkapan keberadaan komite pengawas risiko pada tahun 2015, sebanyak 49 perusahaan pada tahun 2016, dan 54 perusahaan pada tahun 2017.

Nilai Adjusted R Square 0,444 yang memiliki arti variabilitas variabel luas pengungkapan sukarela yang dijelaskan oleh variabilitas variabel KNR serta komite pengawas risiko sebesar $44,4 \%$. Sisanya $55,6 \%$ dijelaskan oleh variabel-variabel lain di luar model penelitian.

Berdasarkan hasil Uji t diperoleh nilai probabilitas variabel keberadaan KNR sebesar 0,134 dan nilai beta sebesar 0,079 . Diperoleh nilai signifikasi $\geq 0,05$. Dapat disimpulkan yaitu keberadaan KNR pada perusahaan

Tabel 3. Uji t

\begin{tabular}{|c|c|c|c|c|c|c|c|}
\hline \multirow[t]{2}{*}{ Model } & \multicolumn{2}{|c|}{$\begin{array}{c}\text { Unstandardized } \\
\text { Coefficients }\end{array}$} & \multirow{2}{*}{$\begin{array}{c}\begin{array}{c}\text { Standardized } \\
\text { Coefficients }\end{array} \\
\text { Beta } \\
\end{array}$} & \multirow[b]{2}{*}{$\mathbf{t}$} & \multirow[b]{2}{*}{ Sig. } & \multicolumn{2}{|c|}{$\begin{array}{c}\text { Collinearity } \\
\text { Statistic }\end{array}$} \\
\hline & $\mathbf{B}$ & Std. Error & & & & Tolerance & VIF \\
\hline $1 \quad$ (Constant) & 26.945 & 0.593 & & 45.419 & 0.000 & & \\
\hline RMC & 9.068 & 0.752 & 0.634 & 12.062 & 0.000 & 0.833 & 1.201 \\
\hline KNR & 1.127 & 0.751 & 0.079 & 1.502 & 0.126 & 0.833 & 1.201 \\
\hline
\end{tabular}

a. Dependent Variable: DSCORE 
manufaktur tidak signifikan terhadap luas pengungkapan sukarela. Dengan demikian, hipotesis pertama tidak diterima. membantu Dekom didalam pelaksanaan tugas serta tanggungjawabnya yang terkait rekomendasi atas nominasi serta remunerasi anggota Dekom, maupun Direksi, anggota

Tabel 4. Uji F

\begin{tabular}{llrrrrr}
\hline & Model & Sum of Squares & df & Mean Square & F & \multicolumn{1}{c}{ Sig. } \\
\hline 1 & Regression & 5354.496 & 2 & 2677.248 & 97.614 & $0.000^{\text {a }}$ \\
\cline { 2 - 7 } & Residual & 6582.450 & 240 & 27.427 & & \\
\cline { 2 - 7 } & Total & 11936.947 & 242 & & & \\
\hline
\end{tabular}

Selanjutnya, nilai probabilitas variabel keberadaan komite pengawas risiko sebesar 0,000 dan nilai beta sebesar 0,634. Diperoleh nilai signifikasi $\leq 0,05$. Dapat disimpulkan yaitu keberadaan manajemen risiko pada perusahaan manufaktur positif signifikan terhadap luas pengungkapan sukarela. Dengan demikian, hipotesis kedua diterima.

Berdasarkan hasil pengujian uji $F$ diperoleh $F$ hitung sebesar 97,614dengan tingkat probabilitas 0,000 signifikan pada 0,05 dikatakan bahwa variabel KNR serta komite pengawas risiko secara simultan memiliki pengaruh atas luasnya tingkat pengungkapan informasi secara sukarela. Dengan demikian, hipotesis ketiga diterima.

\section{Pembahasan}

\section{Keberadaan KNR}

Berdasarkan hasil penelitian diketahui bahwa keberadaan KNR tidak berpengaruh signifikan terhadap luas pengungkapan sukarela. Hal ini ditunjukkan dari nilai probabilitas variabel KNR sebesar 0,126. Diperoleh nilai signifikasi lebih besar dari pada 0,05 . Sehingga, disimpulkan bahwa keberadaan KNR tidak berpengaruh terhadap luasnya suatu pengungkapan sukarela pelaporan keuangan.

KNR yaitu komite yang berperan
Komite tingkat Dekom, maupun Pejabat Eksekutif serta pegawai secara menyeluruh sesuai prinsip $G C G$, yaitu prinsip kewajaran, transparansi, pertanggungjawaban, akuntabilitas, serta kemandirian.

Tugas serta tanggung jawab KNR lebih mengarah kepada kepentingan intern terkait kinerja individu bukan kinerja lembaga, sehingga dapat disimpulkan bahwa keberadaan KNR tidak berhubungan langsung terhadap luas pengungkapan sukarela.

\section{Keberadaan Komite pengawas risiko}

Hasil penelitian diketahui keberadaan komite pengawas risiko berpengaruh signifikan positif terhadap luas pengungkapan sukarela. Hal ini ditunjukkan dari nilai probabilitas variabel RMC sebesar 0,000 . Nilai signifikasi yang diperoleh lebih kecil daripada 0,05. Sehingga, disimpulkan bahwa keberadaan komite pengawas risiko berpengaruh terhadap luasnya pengungkapan sukarela di dalam suatu pelaporan keuangan. Penelitian yang menguji pengaruh keberadaan komite pengawas risiko terhadap luas pengungkapan masih jarang ditemui. Penelitian terdahulu lebih sering menguji pengaruh komite audit terhadap luas pengungkapan sukarela. Ho dan Wong (2001) memberikan bukti empiris bahwa ada pengaruh yang positif antara pengungkapan sukarela

Tabel 5. Ringkasan Hasil Uji Hipotesis

\begin{tabular}{llcc}
\hline No. & Hipotesis & Signifikasi & Hasil \\
\hline 1. & $\begin{array}{l}\text { Keberadaan KNR pada perusahaan manufaktur } \\
\text { berpengaruh terhadap luas pengungkapan sukarela. }\end{array}$ & 0,126 & Tidak Diterima \\
\hline 2. & $\begin{array}{l}\text { Keberadaan komite pengawas risiko pada perusahaan } \\
\text { manufaktur berpengaruh terhadap luas pengungkapan } \\
\text { sukarela. }\end{array}$ & 0,000 & Diterima \\
\hline 3. & $\begin{array}{l}\text { Keberadaan KNR serta komite pengawas risiko pada } \\
\text { perusahaan manufaktur berpengaruh terhadap luas } \\
\text { pengungkapan sukarela. }\end{array}$ & 0,000 & Diterima \\
\hline
\end{tabular}


dengan keberadaan komite audit. Baik komite audit maupun komite pengawas risiko termasuk dalam komite tipe pengawas yang dibentuk oleh dewan komisaris. Keduanya memiliki tugas yang sama yaitu menyediakan pengawasan yang independen dalam berbagai macam aktivitas yang dilakukan dewan dengan tujuan meningkatkan akuntabilitas dewan komisaris dan melindungi para shareholder.

Walaupun keberadaan komite pengawas risiko pada perusahaan manufaktur belum termandatkan, tetapi keberadaan komite tersebut tetap dinilai penting. Keberadaan komite pengawas risiko sebagai komite tipe pengawas merupakan bagian yang penting dari suatu sistem pelaksanaan good corporate governance. Keberadaan komite pengawas risiko akan lebih dapat meminimalisir risiko yang akan dihadapi perusahaan non-finansial. Maka akan berdampak pula pada pelaporan keuangannya yang lebih berkualitas, sehingga perusahaan dapat memberikan pengungkapan informasi secara sukarela lebih luas pula. Pernyataan tersebut diperkuat dengan hasil penelitian ini, yaitu keberadaan komite pengawas risiko pada perusahaan non-finansial signifikan berpengaruh terhadap luasnya pengungkapan sukarela.

Melalui pengungkapan informasi secara sukarela yang lebih luas, nilai perusahaan akan dapat ditingkatkan, karena perusahaan akan memiliki citra lebih peduli dan jujur terhadap dunia dimana perusahaan tersebut berada (Francis, et.al, 2005). Melalui pengungkapan informasi secara sukarela akan dapat mengurangi biaya modal serta peningkatan kredibilitas, dikarenakan asimetri informasi dapat dikurangi (Francis, et.al 2005). Maka dapat diketahui melalui pengungkapan informasi secara sukarela yang lebih lengkap akan memiliki dampak positif terhadap pencapaian pelaksanaan good corporate governance di dalam perusahaan.

\section{Keberadaan Komite Pengawas Manajemen}

Secara bersama-sama keberadaan KNR serta KPR memberikan pengaruh secara signifikan terhadap luasnya pengungkapan pengungkapan informasi secara sukarela yang dilakukan perusahaan manufaktur. Keberadaan mereka secara bersama sebagai KPM berkontribusi terhadap pertanggungjawaban yang dilakukan oleh manajemen atas perusahaan. Perusahaan memiliki tanggung jawab tidak hanya terbatas kepada aspek kinerja keuangan saja, tetapi juga wajib bertanggung jawab terhadap informasi nonfinansial beserta implikasi masalah yang ditimbulkan oleh aktivitas operasional perusahaan. Pengungkapan sukarela merupakan suatu bentuk pertanggungjawaban yang telah semestinya dilakukan oleh perusahaan, baik dampak positif maupun dampak negatif yang ditimbulkan oleh aktivitas operasionalnya, dan memiliki potensi pengaruh terhadap masyarakat internal maupun eksternal dalam lingkungan perusahaan tersebut. Semakin luas tingkat pengungkapan sukarela yang dilakukan oleh perusahaan, maka semakin positif nilai yang tercipta untuk perusahaan atas dirinya di mata para stakeholder.

\section{Kesimpulan dan Saran}

Hasil penelitian disimpulkan bahwa keberadaan komite pengawas risiko signifikan berpengaruh terhadap luas tingkat pengungkapan sukarela pada perusahaan manufaktur. Keberadaan komite ini pada perusahaan manufaktur tetap dinilai sebagai komponen yang penting dari suatu sistem pelaksanaan good corporate governance, meskipun hal tersebut belum termandatkan. Keberadaan komite pengawas risiko akan lebih dapat meminimalisir risiko yang akan dihadapi perusahaan manufaktur. Hal ini akan berdampak pada pelaporan keuangan perusahaan yang lebih berkualitas, sehingga perusahaan akan mampu memberikan pengungkapan sukarela yang lebih luas pula. Semakin luas tingkat pengungkapan informasi secara sukarela, akan memiliki dampak positif atas penilaian kredibilitas maupun nilai perusahaan, yang terefleksi melalui harga saham perusahaan. Penilaian baik stakeholder atas perusahaan diharapkan dapat sebagai mekanisme efektif untuk pencapaian tujuan perusahaan. Berbeda dengan keberadaan komite pengawas risiko yang berpengaruh signifikan, keberadaan KNR tidak signifikan memiliki pengaruh atas luasnya pengungkapan informasi secara sukarela. Pengetahuan akan pentingnya keberadaan komite pengawas manajemen dapat dipertimbangkan lebih lanjut oleh para regulator dan para pelaksana praktek 
good corporate governance. Hal ini agar dapat tercipta praktek good corporate governance yang merata pada seluruh bidang industri.

Terdapat keterbatasan dalam penelitian ini, yaitu bahwa komite pengawas manajemen merupakan isu yang masih baru, sehingga dalam perkembangannya mengakibatkan masih sedikit perusahaan yang mengungkapkan keberadaan komite pengawas manajemen secara jelas. Informasi mengenai komite pengawas risiko hanya diperoleh melalui laporan corporate governance dan laporan komite audit dalam annual report. Saran untuk penelitian selanjutnya adalah dapat menambahkan penggunaan metode pengumpulan data seperti kuesioner maupun wawancara untuk lebih mengetahui informasi secara lengkap mengenai keberadaan komite pengawas manajemen.

\section{Daftar Referensi}

Bothwell, R. (2004). Trends in self-regulation and transparency of non profits in the U. S. The International Journal of Not-for-Profit Law, 7(3). http://www. icnl. org, diakses tanggal 15 September 2005.

Chen, Li, A. Kilgore, and R. Radich. (2009). Audit Committees: Voluntary Formation by ASX Non-Top 500. Managerial Auditing Journal, Vol. 24, No. 5, pp. 475493.

Deegan, C. (2004). Financial Accounting Theory. Sydney: Mc Graw-Hill Book Company.

Francis, J. , Nanda, D. , \& Olsson, P. (2005). Voluntary disclosure, information quality, and costs of capital (Working paper). Durham, NC: Duke University.

Guthrie, J., and L. D. Parker. (1989). Corporate social reporting: a rebuttal of legitimacy theory. Accounting and Business Research. Vol. 19 No. 76. pp. 343-52.

Hendrickson, Eldon, and Michael van Breda. (1992). Accounting Theory 5th ed. Homewood: Irwin.

Ho, S and Wong K. S. (2001). A Study of the Relationship Between Corporate Governance Structures and the Extent of
Voluntary Disclosure. Journal of International Accounting Auditing and Taxation, vol 10.

Jensen, Michael C. and William H. Meckling. (1976). Theory of The Firm: Managerial Behaviour, Agency Costs, and Ownership Structure. http://google. com, diaskes tanggal 9 Mei 2011.

Kangarlouei, S. J., Rezaei, H., Motavassel, M. (2013). The investigation of the effect of voluntary disclosure on earnings quality and cost of capital in firms listed in Tehran Stock Exchange. International Journal of Empirical Finance, Vol. 1, No. 1, 2013, pp. 1-6.

Karolyi, G. A. (1998). Why do companies list shares abroad? A survey of the evidence and its managerial implications. Financial Markets, Institutions and Instruments, 7(1), 1-60.

Khomsiyah. (2005). Analisis Hubungan Struktur Dan Indeks Corporate Governance Dengan Kualitas Pengungkapan. Disertasi S3. Yogyakarta: Universitas Gadjah Mada.

Matoussi, H., \& Chakroun, R. (2008). Board composition, ownership structure and voluntary disclosure in annual reports: Evidence from Tunisia. Laboratoire Interdisciplinaire de Gestion UniversiteEntreprise (LIGUE), 1-28.

Nugroho, Adianto. (2008). Pengaruh Implementasi Struktur Kepemilikan, Struktur Good Corporate Governance, dan Rasio Keuangan terhadap Kinerja Perusahaan Publik di Indonesia. Skripsi. Semarang: Universitas Diponegoro.

Ruigrok, W., S. Peck, S. Tacheva, P. Greve, Yan Hu. (2006). The Determinants and Effects of Board Nomination Committees. Journal of Management Governance, Vol. 10, pp. 119-148.

Subramaniam, Nava, L. Mc. Manus, and Jiani Zhang. (2009). Corporate Governance, Firm Characteristics, and Risk Management Committee Formation in Australia Companies. Managerial Auditing Journal, Vol. 24, No. 4, pp. 316339. 